\title{
Digital rights under the civil law of the Russian Federation
}

\author{
Armine Mograbyan ${ }^{1 *}$ \\ ${ }^{1}$ Volgograd Institute of Management - a branch of the Russian Academy of National Economy and Public \\ Administration under the President of the Russian Federation, 400066, st. Gagarin, 8, Volgograd, Russia, \\ mograbyan-as@ranepa.ru
}

\begin{abstract}
The article discusses a new object of civil rights, which appeared as a result of the addition of the Civil Code of the Russian Federation with article 141.1 "Digital rights". The features of the definition of digital rights in Russian civil law are revealed. Particular attention is paid to the formulation of the concept of digital rights contained in the Civil Code of the Russian Federation. The author draws attention to the fact that according to Russian civil law, digital rights include only those that are directly named as such in the law, which indicates a legislative limitation of their turnover. In addition, the adopted laws on crowdfunding and digital financial assets were reviewed, as well as utilitarian digital rights and digital rights that relate to digital financial assets were analyzed. Attention is also drawn to other problems raised in the science of civil law regarding the modernization of Russian civil legislation in the field of digital rights. The author emphasizes the positive nature of the appearance in the Russian law of norms on digital rights, as an indicator of a legislative response to the digitalization of the economy and law, and a necessary prerequisite for further regulation of civil law relations changing under its influence.
\end{abstract}

\section{Introduction}

In the era of comprehensive digital transformation and the penetration of digital online platforms into all sectors of society [1], changes have affected not only the economy, but also various sectors of law, including Russian private law. This is evidenced by the latest changes in the civil legislation of the Russian Federation. So, from October 1, 2019, Art. 141.1 of the Civil Code of the Russian Federation (State Duma of the Federal Assambly of the Russian Federation [2], 1994), which is called "Digital Rights". This article was introduced by federal law No. 34-FZ of March 18, 2019 [3] in order to adapt the current civil legislation of Russia to the changing public relations for digitalization, in particular, for the adoption of digital financial assets [4] and on attracting investments through an electronic platform [5]. Supplementing the Civil Code of the Russian Federation with the provision on digital rights of witnesses "on the legislative recognition of digital rights as a kind of civil rights from the point of view of civil legislation" [6]. Corresponding changes were made to Article 128 of the Civil Code of the Russian Federation "Objects of Civil Rights" in accordance with various digital legal means, including non-cash funds and uncertified securities. At the same time, it should be noted that the chosen legislative formulation of the concept of digital rights has caused an emergence of numerous discussions in the science of civil law.

\footnotetext{
* Corresponding author: mograbyan-as@ranepa.ru
}

\section{Problem Statement}

Most researchers rightly point out that the introduction of digital rights into the Civil Code of the Russian Federation as one of the objects of civil rights raises many questions and problems, some of which were noted by researchers at the stage of discussing draft laws [7-9]. In particular, L. Novoselova rightly criticizes the term "digital law" used in the Civil Code of the Russian Federation, since it is used in the meaning of the technical term "token to which information about property rights is tied"[10] without explaining the content of the law itself. An interesting position is S. Sarbash, who, noting the controversial nature of the concept of digital rights in civil science, believes that it is not new for civil law science. In his opinion, "Digital law, in fact, is only a form, that is, the registration of any known law: proprietary, obligatory, corporate, exclusive, personal. Digitalization as such and digitalization of the economy are only a method of registration, but not the content of property relations" [10]. Perhaps it is difficult to disagree with this. M.A. Rozhkova is also in solidarity with the opinion that the concept of digital rights introduced into the Civil Code of the Russian Federation in the existing edition is insolvent: "Digital rights" have obviously become superfluous" [11].

It should also be noted that the concept of "digital rights" used in the Civil Code of the Russian Federation is rather narrow, and, judging by the legal definition, it 
includes only "obligations and other rights named in such a capacity in the law, the content and conditions of implementation of which are determined in accordance with the rules of an information system that meets the characteristics established by law." [2] In this definition, a number of restrictions on the classification of rights as digital can be distinguished. First, they must be named as such in the statute. Secondly, their content and conditions for implementation must be determined in accordance with the rules of the information system. Thirdly, the named information system must meet the criteria established by law. In addition, the law establishes that the implementation and disposal of digital rights, as well as the limitation of the order, are possible only in the information system, while contacting a third party is not required for this [2]. As a general rule, the holder of a digital right is a person who can dispose of it in accordance with the rules of the information system. The exceptions are cases provided by law and certain grounds when another person is recognized as the owner of a digital right [2]. At the same time, in the case when the basis for the transfer of digital rights is a transaction, then the consent of the person obliged under such a right to transfer is not required [2]. Thus, an analysis of Article 141.1 of the Civil Code of the Russian Federation allows us to speak of a legislative limitation in the turnover capacity [12] of digital rights as objects of civil law.

To date, only one legislative act has come into force, which mentions digital rights - Federal Law of August 2, 2019 No. 259-FZ "On attracting investments using investment platforms and on amending certain legislative acts of the Russian Federation" (hereinafter Crowdfunding Law). In particular, the digital rights provided for by the law include the "utilitarian digital rights" [5] named in Article 8 of the Crowdfunding Law: demand the transfer of things or exclusive rights to use them, as well as demand the performance of work and (or) the provision of services. At the same time, these rights are recognized as digital only if they originally arose as such on the basis of an agreement for the acquisition of utilitarian digital rights, which was concluded using an investment platform, in accordance with the rules established by law. At the same time, the right to claim property, the rights to which or transactions with which are subject to state registration or notarization, cannot be utilitarian digital rights [5]. Analysis of Article 8 of the Law on Crowdfunding suggests that along with state registration and notarization, another form of certification of property rights has appeared in the law - digital. At the same time, this concept is not consistent with the design of Article 128 of the Civil Code of the Russian Federation, in which digital rights are named as one of the varieties of property rights, along with non-cash funds and uncertified securities. In this regard, the opinion of A. Asoskov is correct, who believes that the legislator has formulated a new, along with uncertified securities, method of certifying property rights [10].

In addition to the Law on Crowdfunding, as part of the implementation of Article 141.1 of the Civil Code of the Russian Federation, another legislative act was adopted - the Law on Digital Financial Assets, which comes into force on January 1, 2020, with the exception of certain provisions for which the law provides for a different period. The said Law provides for one more, in addition to utilitarian, type of digital rights - digital financial assets, which are understood as digital rights, including monetary claims, the possibility of exercising rights under equity securities, the right to participate in the capital of a non-public joint stock company, the right to demand the transfer of equity securities, which are provided for by the decision on the release of digital financial assets in the manner prescribed by law, the release, accounting and circulation of which is possible only by making (changing) entries in the information system based on the distributed register, as well as in other information systems (State Duma, 2020). As you can see, the legislator has distinguished between utilitarian digital rights, which cannot be for monetary claims, from digital financial assets, which cannot be for things, works, services and results of intellectual activity. At the same time, in accordance with the new edition of Article 8 of the Law on Crowdfunding, from January 1, 2021 , it will be provided as an opportunity to acquire and dispose of digital financial assets, as well as digital rights, including both utilitarian digital rights and digital financial assets, in the investment platform; and the possibility of executing transactions with utilitarian digital rights through the operator of the exchange of digital financial assets. But the Law on Digital Financial Assets contains restrictions for credit institutions, in particular, the latter cannot perform the functions of operators of investment platforms. Thus, "the legislation of the Russian Federation allows, based on the functioning of utilitarian digital rights and digital financial assets in one complex information system, to organize the circulation of a wide variety of digital assets, including those tied to monetary claims and physical assets" [13].

Another problem in the field of civil legal regulation of digital rights, which has been repeatedly raised by civil lawyers, is seen from the analysis of Article 141.1 of the Civil Code of the Russian Federation and Article 8 of the Law on Crowdfunding and is associated with the restriction in terms of contacting a third party. In particular, we are talking about the possibility of exercising, ordering and restricting the disposal of digital rights only in the information system without contacting a third party. In this regard, absolutely fair questions are posed by S. Sarbash: "If some entity in circulation is ready to provide this or that benefit both by referring to the information system, and without referring to it, then the right, formalized in digital, becomes something else? I have already cited an example with a bank account agreement, where a person has an alternative: either interact with the bank through appropriate programs, or go to a bank branch. Do my rights in the second case stop being digitalized? After all, in the bank, the owner will not require anything except a passport, but the rights, as they were in digital form, remain. Why does the legislator limit our opportunities? Or is that not what you mean?" [10]. 
Civilists also identify a number of other problematic issues in the area under study. So, for example, an important remark regarding the legal definition of digital rights was made by A. Semenov, who draws attention to the separation of the authority to order from the exercise of digital law, "which suggests a certain doctrinal turn of codifiers to the relationship of these concepts, since earlier the exercise of the right included number and disposal of them." [10] As you can see, the addition of civil legislation with a rule on digital rights has led to the emergence of numerous discussions and questions to be answered by the legislator, including after a collision with the practice of resolving disputes arising in the new digital reality.

\section{Research Questions}

The article is aimed at solving the following research questions:

- What is the specificity of the definition of digital rights in Russian civil law?

- Has the introduction of norms on digital rights into the Civil Code of the Russian Federation solved the challenges of reality in the field of regulation of private-law relations changing in the context of the digitalization of the economy and society?

\section{Purpose of the Study}

On the basis of a comprehensive analysis of theoretical provisions and legal regulation, identify the specific features of the legal definition of digital rights in the civil law of Russia, and assess the emergence in the legislation of the new concept of "digital rights" for Russian civil law.

\section{Research Methods}

Both general scientific and sectoral research methods were used as the main ones, in particular, analysis, synthesis, comparative legal, formal legal, logical, systemic and others.

\section{Findings}

Given the speed of change in public relations, it is difficult for a legislator to keep up with it, and such a restriction will generate many problems associated with the unsettledness of changing civil law relations. A specific feature of digital rights in Russian civil law is the fact that the law significantly restricts the range of rights that can be classified as digital, in comparison with foreign legal systems [14,15], which, inevitably, gives rise to legally unregulated public relations in the private law sphere, which, in turn, gives rise to corresponding problems in practice. On the other hand, the emergence of the very concept of "digital rights" in the civil legislation of Russia is a positive factor on the way to the settlement of private law relations arising in the new reality.

\section{Conclusion}

Thus, despite the well-founded criticism of the legal definition of digital rights and its content, the very fact of the appearance in the Civil Code of the Russian Federation of the concept of "digital rights", which means the private law regulation of this concept, deserves positive attention, since it indicates the desire of the legislator, albeit not always ahead of reality and timely, to promptly respond to objective changes in law and economy in the era of global digitalization.

\section{References}

1. J. Van Dijck Computer Law \& Security Review 36, 105377 (2020)

2. State Duma of the Federal Assambly of the Russian Federation Civil Code of the Russian Federation. Part one (November 30, 1994 No 51-FZ) (as revised July 31, 2020). (Moscow, Russia, 1994)

3. State Duma of the Federal Assambly of the Russian Federation Federal Law "On Amendments to Parts One, Two and Article 1124 of Part Three of the Civil Code of the Russian Federation" (March 18, 2019 No. 34-FZ) (Moscow, Russia, 2019a)

4. State Duma of the Federal Assambly of the Russian Federation Federal Law "On digital financial assets, digital currency and on amendments to certain legislative acts of the Russian Federation" (July 31, 2020 No. 259-FZ) (Moscow, Russia, 2020)

5. State Duma of the Federal Assambly of the Russian Federation Federal Law "On attracting investments using investment platforms and on amending certain legislative acts of the Russian Federation" (August 2, 2019 No. 259-FZ) (as amended on July 20, 2020). Moscow, Russia, 2019b)

6. D.A Petrov, V.F. Popondopulo, E.V. Silina, Digital law (Moscow, Prospect, 2020)

7. A. Savelyev, Computer Law \& Security Review 34(4), 863-869 (2018)

8. A.M. Erdelevsky, About digital rights (2019), URL:http://www.consultant.ru/cons/cgi/online.cgi?req= doc\&base $=$ CJI\&n=122169\#07570494312440597 (date of access: 16.03.21).

9. R.B. Golovkin, O.S. Amosova, Bulletin of the Vladimir Law Institute 2(51), 163-166 (2019)

10. L. Novoselova, A. Gabov, A. Savelyev, A. Genkin, S. Sarbash, A. Asoskov, A. Semenov, R. Yankovsky, A. Zhuravlev, A. Tolkachev, A. Kamelkova, M. Uspensky, R. Krupenin, V. Kislyi, M. Zhuzhzhalov, V. Popov M. Agranovskaya, Law. 5, 31-54 (2019)

11. M.A. Rozhkova, Economy and law 10, 3-12 (2020).

12. L.V. Borisova, Actual Problems of Russian Law 1(74), 126-131 (2017)

13. A. Lisitsyn, Settlements and operational work in a commercial bank 4, 4-17 (2020)

14. E.M. Weitzenboeck Computer Law \& Security Review 29(3), 293-295 (2013, June). 
15. M.A. Rozhkova Digital rights - what are they and are they needed in the Civil Code? [Blog post] (2020)

URL:

https://zakon.ru/blog/2020/08/17/cifrovye_prava_di gital_rights_chto_eto_takoe_i_nuzhny_li_oni_v_gr azhdanskom_kodekse (date of access: 16.03 .21 ) 